\title{
Micropuncturing the Nephron
}

\author{
Volker Vallon \\ Departments of Medicine and Pharmacology, University of California San Diego \& VASDHCS, San \\ Diego, CA, USA
}

\section{Summary}

To achieve the role of the kidney in maintaining body homeostasis, the renal vasculature, the glomeruli, and the various segments of the nephron and the collecting duct system have to fulfil very diverse and specific functions. These functions are dependent on a complex renal architecture and are regulated by systemic hemodynamics, hormones and nerves. As a consequence, to better understand the physiology of the kidney, methods are necessary that allow insights on the function of these diverse structures in the physiological context of the intact kidney. The renal micropuncture technique allows direct access to study superficial nephrons in vivo. In this review, the application of micropuncture techniques on the single nephron level is outlined as an approach to better understand aspects of glomerular filtration, tubular transport, and tubulo-glomerular communication. Studies from the author's lab, including experiments in gene-targeted mice, are briefly presented to illustrate some of the approaches and show how they can further advance our understanding of the molecular mechanisms involved in the regulation of kidney function.

In 1924, Wearn and Richards (83) published one of the most important single contributions to renal physiology as Gottschalk noted in 1992 (22). Wearn and Richards had developed and applied the method of micropuncture in frogs. The work provided the first experimental evidence that macromolecules like proteins were excluded from the glomerular fluid in Bowman's space. Moreover, they reported that concentrations of glucose, chloride, potassium, urea, and $\mathrm{pH}$ in glomerular fluid were essentially identical to the aqueous phase of plasma. These findings supported the concept proposed earlier by Ludwig that tubular fluid is formed by a process of ultrafiltration across a capillary, which excluded large proteins (38;39). Wearn and Richards also provided first evidence for tubular reabsorption in as much as the bladder urine was free of sodium chloride and glucose (83). Subsequently, Richards and Walker developed methods for micropuncturing surface nephrons in Necturus and frogs and perfused proximal or distal convoluted tubules in situ (46), and Walker and Hudson showed that glucose was reabsorbed from the proximal convoluted tubule (80). In 1941, Walker and colleagues successfully applied micropuncture in the mammalian kidney (81) and basically confirmed the above findings in Necturus and frog. In addition, they showed that at least two-thirds of the filtered fluid is reabsorbed by the proximal tubule, the latter in an isosmotic way. In comparison, the chloride concentration in the proximal tubule increased to a value 1.4-fold higher than plasma, and they suggested that bicarbonate could have preferentially be reabsorbed over chloride (79). Subsequent milestones included the micropuncture demonstration by Gottschalk and Mylle in 1959 (24) that tubular fluid at the tip of long loops of Henle is hypertonic and isosmotic with both the blood in the vasa recta and urine in adjacent collecting ducts at the same level of the papilla during antidiuresis. Together with previous work by Wirz, Hargitay and Kuhn (86-88) these findings provided decisive evidence for the countercurrent hypothesis

Address for correspondence: Volker Vallon, MD, Departments of Medicine and Pharmacology, University of California San Diego \& VA San Diego Healthcare System, 3350 La Jolla Village Drive (9151), San Diego, CA 92161, Phone: 858-552-8585 ext. 5945, Fax: 858-642-438,vvallon@ucsd.edu. 
of urine concentration. Micropuncture continued to play a critical role for gaining further insights in renal physiology. To name a few, Thurau and Schnermann in the mid sixties described the regulation of nephron filtration rate by tubuloglomerular feedback $(47 ; 60)$, whereas in the early seventies, Brenner and Blantz had started to use micropuncture to perform a complete analysis of the physical factors determining the glomerular filtration rate (GFR) $(4 ; 8)$. To gain the insights outlined in this introduction, it was essential to study the diverse renal structures in the physiological context of the intact kidney.

In recent years, the availability of gene-targeted mice provided a new opportunity to better understand the molecular determinants of kidney function. While there is a new need for the application of micropuncture and microperfusion techniques, the number of physiologists competent of performing these challenging techniques is decreasing. In this review, the in vivo application of micropuncture techniques on the single nephron level to study aspects of glomerular filtration, tubular transport, and tubulo-glomerular communication is described. The review reflects the author's experience and the methods that worked for him. Studies from the author's lab, including experiments in gene-targeted mice, are briefly presented to illustrate some of the approaches. The interested reader is referred to previous reviews on micropuncture techniques $(20 ; 23 ; 84 ; 85)$ including special considerations for the mouse $(36 ; 42 ; 61)$.

\section{General considerations}

Renal micropuncture provides the unique opportunity to study single nephron function in the intact kidney and thus in the context of the complex renal architecture and the regulation by systemic hemodynamics, hormones and nerves. However, the application of micropuncture techniques is difficult considering the need for microsurgery, careful preparation of the kidney, and direct puncturing of the small kidney structures. In addition, the analysis of nanoliter volumes is challenging. As a consequence, micropuncture studies can be prone to generating substantial data scatter and thereby inconclusive data. Significant experience is necessary for the generation of reasonable micropuncture data and their interpretation. Considerations to keep in mind for data interpretation include the fact that micropuncture is performed on the subgroup of superficial nephrons whereas deeper nephrons are not accessible. Micropuncture is done in certain species, now mostly rats and mice, and extrapolation to other species such as humans must be made (mice are chosen because of lower costs (e.g. compared with dogs) and especially because of the possibility of selective gene-targeting; see below). Moreover, micropuncture requires surgical preparation and the presence of anesthesia both of which can affect kidney function.

\section{Animal and kidney preparation for micropuncture}

Rats are usually anesthetized with thiobutabarbital (Inactin ${ }^{\circledR}, 100 \mathrm{mg} / \mathrm{kg}$ intraperitoneally) providing adequate relaxation for the course of an entire experiment. In mice, inactin is not sufficient as a single anesthetic, but requires combination with ketamine (100 mg/kg i.m.). Gas anesthesia using halothane or isoflurane is another option that may interfere less with vascular reactivity (34). Body temperature must be monitored and regulated by heat application since both rats and mice rapidly cool off during anesthesia. We adjust the rectal temperature in the rat to $37^{\circ} \mathrm{C}$ and to $37.5-38^{\circ} \mathrm{C}$ in the mouse using a temperature controlled operating table (e.g. Klaus Effenberger, Med.-Tech. Gerätebau, Pfaffing/Attel, Germany; Vestavia Scientific, Birmingham, AL). A tracheostoma is placed to facilitate breathing. To replace surgical fluid losses animals typically receive an electrolyte maintenance infusion, but the exact protocol to achieve "euvolemia" varies between laboratories. Infusion rates are in the order of $0.5-1 \mathrm{ml} /$ $\mathrm{hr} / 100 \mathrm{~g}$ in rats and $1-1.5 \mathrm{ml} / \mathrm{hr} / 100 \mathrm{~g}$ in mice, and infusion solutions are electrolyte solutions with the addition of a colloid (for example $4 \mathrm{~g} / \mathrm{dl}$ albumin). 
Critical for successful micropuncture is to prevent movement of the kidney (e.g. from breathing of the animal) without impairing renal blood flow or compressing the kidney. Figure 1 illustrates the preparation of the left kidney (because its vessels are longer than those of the right). After completion of the preparation, a piece of parafilm sparing the kidney holder is placed on the animal to close the opening and prevent body fluid and heat loss. In such a preparation kidney function is stable for several hours in the rat, but limited to $\sim 1-2$ hours in mice.

\section{Identification of kidney structures accessible by micropuncture on the kidney surface}

Using a stereomicroscope with magnification to at least 150x (working distance of 2-3 cm is important for introduction of micropipettes) and a fiber optic light guide provides a view on the kidney surface similar to Figure 2. The structures seen include tubules, peritubular capillaries, and, in young animals or rat strains like Munich-Wistar or Munich-Wistar-Fromter, also glomeruli ( 2-10 accessible to micropuncture)(the Munich-Wistar-Fromter strain needs special caution since it represents a genetic model with an inherited nephron deficit exhibiting mild hypertension and progressive albuminuria). Most of the tubular structures are proximal tubules (S1 and S2) with some distal convoluted tubules, connecting tubules and few collecting ducts, with practically all segments deriving from superficial nephrons. About $60-80 \%$ of the nephrons with accessible proximal tubular surface loops have also an accessible distal segment on the kidney surface. Importantly, segments from deeper nephrons do not gain access to the kidney surface. As a consequence, most micropuncture experiments are performed in tubular structures from superficial nephrons only. Potential functional differences between nephron populations (e.g., between juxtamedullary and superficial nephrons) have to be considered $(31 ; 33)$.

Glass capillaries (outer/inner diameter $\sim 0.9 / 0.5 \mathrm{~mm}$; e.g. Warner Instrument Corp., Hamden, CT; WPI, Sarasota FL; Corning Incorporated, Corning, NY) are pulled, grinded and mounted in a capillary holder that is placed on a micromanipulator (e.g. Leitz; Leica Vertrieb GmbH, Bensheim, Germany). The capillary holder is connected to an air-filled glass syringe by polyethylene tubing. Applying pressure or suction via the glass syringe allows infusing or withdrawing fluid through the capillary tip. A nephron is identified by puncturing Bowman space (when superficial glomeruli are accessible) or a long proximal tubule segment with a pipette containing stained artificial tubular fluid (ATF; see Table 1), and observing staining of downstream loops (Figure 2).

Table 2 provides a list of suggested outer diameters for micropuncture capillaries used for the different applications. The tips of the capillaries are grinded and sharpened for easier puncturing of the target structures. The orientation of the opening is marked on the capillary during grinding. For most applications, the target structures are punctured with the opening of the grinded tip facing up. The opening of a capillary to collect blood from peritubular star vessels, however, faces down; this facilitates the collection of blood, which flows perpendicular from the depth of the kidney to the kidney surface and thus directly into the capillary.

\section{Collection of tubular fluid}

The collection of tubular fluid is an important method for the assessment of glomerular filtration as well as tubular transport processes and therefore is introduced first. Tubular fluid is quantitatively collected from a proximal or distal tubular site using a pipette, the tip of which is filled with stained water-saturated oil (e.g. $2 \%$ Sudan black B-stained mineral oil). After puncturing the tubule, a small amount of oil is injected. The injected oil will start to move with the current of tubular fluid. An oil column with a length of about 4-5 tubular diameters is 
generated before suction is briefly applied via the glass syringe. This will initiate the collection of tubular fluid into the capillary while the oil block in the tubule prevents downward escape. The aim is to obtain a quantitative collection of tubular fluid with minimal effect on tubular pressure. In general this is achieved when the collection is performed in a "spontaneous" way that requires minimal manipulations of the glass syringe. In general, standard collection techniques do not alter intraluminal pressure significantly. Intentional reduction in intratubular pressure are not reflected by measurable changes in single nephron GFR when late proximal fluid collections are performed (11). At the completion of the tubular fluid collection, the glass capillary is withdrawn from the tubule into the oil layer covering the kidney. A small amount of oil is aspirated and the collection thus sealed between oil.

The tubular flow rate $\left(\mathrm{V}_{\mathrm{TF}}\right)$ is determined by transferring the collected fluid to a constant bore capillary (e.g. Hirschmann Inc. Laboratory Equipment, Louisville, KY), connected to an airfilled glass syringe, to determine the total volume, which is divided by the collection time. The constant-bore capillary is preloaded with a drop of water-saturated oil, the collection pipette carefully inserted, and the oil column splitted by injecting the tubular fluid. Gentle suction is applied via the glass syringe as necessary when the fluid is transferred to prevent spilling at the injection side. The length of the tubular fluid column (packed between oil) is determined.

\section{Measurement of SNGFR}

The GFR defines the filtered load to each nephron and is a critical determinant of renal transport work. In general, inulin is used to determine whole kidney GFR as well as single nephron GFR (SNGFR). About $120 \mu \mathrm{Ci} / \mathrm{h}$ of $\left[{ }^{3} \mathrm{H}\right]$-inulin is continuously infused i.v. in the rat and $\sim 50 \mu \mathrm{Ci} /$ $\mathrm{h}$ in the mouse. $\left[{ }^{3} \mathrm{H}\right]$-inulin is relatively unstable requiring dialysis to remove free $\left[\mathrm{H}^{3}\right]$.

Alternatively, ${ }^{125}$ I-iothalamate or FITC-labeled inulin have been used (37). The tubular fluid is quantitatively collected from a proximal or distal tubular site as described above. For assessment of ambient SNGFR, collections from the distal tubule are preferred since the macula densa influence on SNGFR is intact.

$\mathrm{V}_{\mathrm{TF}}$, the concentration of inulin in the collected tubular fluid $\left(\mathrm{TF}_{\mathrm{In}}\right)$, and the concentration of inulin in plasma $\left(\mathrm{P}_{\mathrm{In}}\right)$ are used to calculate SNGFR:

$$
\operatorname{SNGFR}(\text { nl } / \mathrm{min})=V_{T F}(n l / \mathrm{min}) x\left(T F_{I n} / P_{I n}\right)
$$

Normal values for SNGFR in the rat and the mouse are in the range of $\sim 30-45$ and $\sim 8-14 \mathrm{nl} /$ min, respectively, dependent on body and kidney weight. Single values that are considerably smaller or greater may indicate problems with the fluid collection. Whereas low values may indicate incomplete collections, values from distal tubules that are about twice the expected normal value may reflect collections from a superficial collecting duct. For further considerations and potential errors see $(1 ; 11 ; 90)$.

\section{Mathematical model of glomerular hemodynamics}

The micropuncture analysis of glomerular hemodynamics allows to assess the physical factors that determine glomerular filtration rate including the glomerular ultrafiltration coefficient (LpA). For a more extensive coverage see $(5 ; 12 ; 56)$. The approach has been extensively used in the rat but not yet in the mouse.

Deen, Robertson, and Brenner developed a mathematical model for computing the physical determinants of SNGFR from micropuncture data (12). This model treats the glomerular capillary as a circular cylinder of unit length, uniform permeability to water and small solutes, 
and zero permeability to protein. In this model, SNGFR is the product of LpA and the effective filtration pressure (EFP) integrated along the glomerular capillary:

$$
\operatorname{SNGFR}=\operatorname{LPA} \cdot \int[\operatorname{EFP}(x)] d x
$$

where $\mathrm{x}$ is the axial position along the nondimensionalized glomerular capillary. EFP is the "Starling force" given by the difference between the hydrostatic pressure gradient ()P) driving glomerular filtration and the oncotic pressure of plasma proteins opposing filtration (B)(the protein concentration in Bowman space is ignored for simplicity):

$$
E F P(x)=) P B(x) .
$$

) $\mathrm{P}$ is the difference in the hydrostatic pressure between the glomerulus $\left(\mathrm{P}_{\mathrm{GC}}\right)$ and Bowman's space or proximal tubule $\left(\mathrm{P}_{\mathrm{PT}}\right)$ : $) P=P_{G C}-P_{P T}$. Whereas $) \mathrm{P}$ changes minimally along the glomerular capillary, the protein oncotic pressure $\mathrm{B}$ increases significantly as a consequence of glomerular filtration. B is calculated from the protein concentration (C) by a simplification of the relationship described by Landis and Pappenheimer (4). $\mathrm{C}(\mathrm{x})$ is calculated with the boundary conditions $\mathrm{C}(0)=\mathrm{C}_{\mathrm{A}}$ and $\mathrm{C}(1)=\mathrm{C}_{\mathrm{E}}$, with $\mathrm{C}_{\mathrm{A}}$ and $\mathrm{C}_{\mathrm{E}}$ being the afferent/preglomerular and efferent/postglomerular plasma protein concentration, respectively. The increase in $B$ along the glomerular capillary can be computed from mass balance considerations for protein and water, and, importantly, is dependent on the single nephron plasma flow SNPF. SNPF is determined as: $S N P F=S N G F R / S N F F$, with $\mathrm{SNFF}$ being the single nephron filtration fraction. $\mathrm{SNFF}$ is given by the increase in $\mathrm{C}_{\mathrm{E}}$ versus $\mathrm{C}_{\mathrm{A}}$ as a consequence of glomerular filtration: $S N F F$ $=\left(1-C_{A} / C_{E}\right)$. The specific profile of EFP and a value for LpA can be determined with a standard root-finding algorithm using the following input data: (1) single nephron plasma flow (SNPF), (2) )P, (3) $\mathrm{C}_{\mathrm{A}}$, and (4) $\mathrm{C}_{\mathrm{E}}(4 ; 12 ; 56)$.

\section{Measurement of glomerular hemodynamics by micropuncture}

Based on the above, the following parameters have to be directly assessed by micropuncture: SNGFR, $\mathrm{P}_{\mathrm{GC}}, \mathrm{P}_{\mathrm{PT}}, \mathrm{C}_{\mathrm{A}}$ and $\mathrm{C}_{\mathrm{E}}$; with secondary calculation of the others. Hydrostatic pressures in vessels and tubules are directly measured with a servo-nulling pressure device $(5 ; 14)$ (WPI, Sarasota, FL). This approach bases on an electrical Wheatstone bridge, the high resistance point of one arm being at the tip of a $1-2 \mu \mathrm{m}$ micropipette that is filled with a $1.5 \mathrm{M} \mathrm{NaCl}$ solution. The hypertonic saline in the pipette has a much greater electrical conductivity than the tubular fluid or plasma. As a consequence, tubular fluid or plasma entering the capillary tip increases the total resistance of the electrical circuit. A pressure (and vacuum) source is linked to the micropipette to reset the total electrical resistance to a preset value. The required pressure corresponds to the hydrostatic pressure in the tubule or vessel that is punctured. In superficial glomeruli, $\mathrm{P}_{\mathrm{GC}}$ can be directly measured by puncturing the glomerular capillaries. Otherwise, $\mathrm{P}_{\mathrm{GC}}$ can be calculated from the stop-flow pressure $\left(\mathrm{P}_{\mathrm{SF}}\right)$ measured in very early proximal tubules upstream of an obstructing wax block (using paraffin wax (semisolid at 42-44EC) and a hydraulic microdrive (e.g. Vestavia Scientific, Birmingham, AL)): $P_{G C}=$ $P_{S F}+B_{A}$ with $\mathrm{B}_{\mathrm{A}}$ being the afferent or preglomerular oncotic pressure. To determine $\mathrm{C}_{\mathrm{A}}$ and $\mathrm{C}_{\mathrm{E}}$, systemic arterial blood is sampled from an arterial catheter and efferent arteriolar blood by direct micropuncture of efferent "star" vessels on the kidney surface. Both afferent and efferent protein concentrations are measured by a microadaptation of the Lowry technique $(5 ; 7)$.

Table 3 shows typical values for the physical determinants of SNGFR as determined by micropuncture in the rat under different volume states. Compared with other capillary systems, 
glomerular filtration is a process driven by a small pressure gradient through a highly waterpermeable filter. Based on the outlined model, SNGFR can be increased by raising )P, SNPF, or $\mathrm{LpA}$, or by reducing $\mathrm{C}_{\mathrm{A}}$; for a more detailed discussion see (56).

\section{Tubular transport}

In general, transport can be studied under free-flow conditions, i.e. glomerular filtration is intact and endogenous tubular fluid is collected for further analysis. Alternatively, a tubular segment can be functionally isolated and microperfused with artificial tubular fluid or with endogenous tubular fluid harvested before. These two approaches are further outlined in the following.

\section{Free-flow collection}

Intratubular factors that may derive from glomerular filtration and/or tubular secretion and that affect transport from the lumen are present in physiological concentrations and can be measured or inhibited. This approach has been critical in establishing the qualitative and quantitative contribution of the different segments to overall kidney function and revealed insights into complex intra-renal mechanisms, e.g. the urinary concentrating mechanism or urinary acidification (40).

Timed and quantitative free-flow collections of tubular fluid can be made along the segments accessible to micropuncture; the collection technique is basically as described above for the determination of SNGFR. The collected tubular fluid is analyzed for SNGFR, $\mathrm{V}_{\mathrm{TF}}$, and for the substance of interest $\mathrm{X}\left(\mathrm{TF}_{\mathrm{X}}\right)$. For the latter, defined volumes can be withdrawn from the sample in the constant bore capillary using pulled and calibrated glass pipettes (e.g., $~ 1-2$ nanoliters). Table 4 provides a list of substances or parameters that can be measured by direct analysis in nanoliters of tubular fluid. The remainder of the collected tubular fluid sample is used to determine $\left[{ }^{3} \mathrm{H}\right]$-inulin and thus SNGFR taking into consideration the volume withdrawn for further analysis. In addition, the freely filtered concentration of $\mathrm{X}$ in plasma $\left(\mathrm{P}_{\mathrm{X}}\right)$ is determined. This allows to calculate the amount of $X$ filtered in the glomerulus (SNGFR $x$ $\left.\mathrm{P}_{\mathrm{X}}\right)$ and the amount that reaches the site of micropuncture $\left(\mathrm{V}_{\mathrm{TF}} \mathrm{X} \mathrm{TF}_{\mathrm{X}}\right)$. From these data, net absolute or fractional reabsorption or secretion $(\mathrm{R} / \mathrm{S})$ of $\mathrm{X}$ up to the site of micropuncture can be calculated.

$$
\begin{array}{ccc}
\text { Absolute } R / S \text { of } X & =(S N G F R \times P x)-\left(V_{T F} \times T F_{X}\right) \\
\text { Fractional } R / S \text { of } X & = & \text { Absolute } R / S \text { of } X /\left(S N G F R \times P_{x}\right)
\end{array}
$$

The site of micropuncture can be defined as the first or last surface loop of proximal tubule on the kidney surface or the first or last surface loop of the distal tubule. The puncturing site or the length of the studied tubular segment can be measured more directly by marking sites of micropuncture with nigrosine or by filling the tubule after the functional analysis with a silicone rubber solution (Microfil; Flow Tech, Carver, MA) and subsequent microdissection and measurement of the length $(10 ; 79 ; 81)$.

\section{Free-flow reabsorption profiles}

Puncturing different sites along the nephron and analyzing urinary excretion at the same time allows to generate a reabsorption profile along the tubular and collecting duct system. In this profile, the reabsorption between the last proximal and the first distal surface loop is an indirect measure for the reabsorption in the loop of Henle (plus early distal convoluted tubule if a nephron with no superficial glomerulus is punctured). Comparing the fractional reabsorption up to the last surface loop of the distal tubule and up to the urine can provide insights on transport in the collecting duct (see example below). Alternatively, the function of papillary 
structures such as the thin limbs of Henle's loop and the collecting duct can be determined by direct micropuncture. The golden hamster, kangaroo rat or young Wistar rats have been used for that purpose since their papilla protrudes several millimeters into the renal pelvis, where they are accessible to micropuncture $(24 ; 31)$. For further details and considerations on freeflow collections see $(9 ; 11)$.

Reabsorption profiles can also be generated along one nephron segments accessible to micropuncture, i.e. along the proximal convoluted tubule or along the distal surface segments. This can be done by performing random fluid collections in these segments and using functional reference markers to further localize the site of tubular fluid collection along the segment. This is illustrated in two examples. In the first example, reabsorption profiles were generated along the proximal tubule. The fractional reabsorption of fluid was used as the reference marker with lower and higher values indicating collections in earlier and later segments of the proximal tubule, respectively. By relating the fractional reabsorption of glucose or $\mathrm{K}^{+}$to the fractional reabsorption of fluid, reabsorption profiles along the proximal tubule were generated for glucose and $\mathrm{K}^{+}$(see Figure 3)(66).

In the second example, a reabsorption profile was generated along the distal segments accessible to micropuncture. The $\mathrm{Ca}^{2+}$ channel TRPV5 is a prominent candidate for active $\mathrm{Ca}^{2+}$ reabsorption and expressed in the luminal membrane of the late distal convoluted tubule and the connecting tubule, i.e. in nephron segments directly accessible to micropuncture. $\mathrm{Ca}^{2+}$ reabsorption was assessed by micropuncture in TRPV5 -/- mice (25). Since $\mathrm{K}^{+}$secretion occurs along the distal segments accessible to micropuncture (together with water reabsorption in connecting tubule and cortical collecting duct), the distal luminal concentration of $\mathrm{K}^{+}$was used as a reference marker for the site of collection along the distal segments $(25 ; 43)$ (see Figure 4). Alternatively, the ratio of $\mathrm{K}^{+}$over $\mathrm{Na}^{+}$can be used since the former is secreted and the latter reabsorbed along the distal segments (35). Using functional reference markers is less tedious than identifying puncturing sites by microdissection but requires that the behaviour of the reference marker is not different between the compared experimental conditions.

In some situations, information on the local conditions or the local composition of the tubular fluid rather than the upstream reabsorption is important. Examples include the the transepithelial potential (e.g. $(16 ; 17)$ ), the composition of glomerular fluid (83), or local concentrations of ions (67) or hormones (58) that act from the tubular lumen. Another example is the osmolality of tubular fluid as outlined before (24) and in the following. A hallmark of proximal tubule function is the near-isosmolar reabsorption of fluid and electrolyte $(24 ; 79)$. The water channel aquaporin-1 (AQP1) is expressed in the apical and basolateral membrane of proximal tubule cells, where it was proposed to provide an important water-selective pathway for transcellular fluid transport. Free-flow micropuncture was performed in mice lacking AQP1 and in wild-type mice to determine and compare the osmolalities in plasma and late proximal tubular fluid (73)(see Figure 5).

\section{Microperfusion to study transport}

A segment of interest (e.g., from early to late proximal tubule $(69 ; 72)$ or from last proximal to first distal loop (27-29;69)) is perfused with a defined flow rate and solution. In general, the composition of the artificial tubular fluid is adapted to the composition of endogenous tubular fluid at the perfusion site (Table 1). The great advantage of this approach is that the composition of the perfusate and the perfusion rate can be controlled and manipulated. After mapping of the nephron, an immobile wax block is inserted just upstream of the segment of interest. The segment upstream of the wax block is vented (by inserting a relatively large capillary). The segment just downstream of the wax block is punctured with a capillary filled with a defined stained perfusion solution and inserted into a servo-regulated microperfusion system ("nanoliter pump"; e.g. Wolfgang Hampel, Neu-Isenburg, Germany; Vestavia Scientific, 
Birmingham, AL). These microperfusion systems can deliver fluid in the range of 0 to $40 \mathrm{nl} /$ min with a precision of $\sim \pm 1-2 \mathrm{nl} / \mathrm{min}$. After perfusion for a specific time (e.g. $1 \mathrm{~min}$ ) a quantitative collection of tubular fluid is initiated and performed from the distal site of the perfused segment. The collection is analyzed for $\mathrm{V}_{\mathrm{TF}}$ and substances of interest. [ $\left.{ }^{3} \mathrm{H}\right]$-inulin can be added to the perfusion fluid and analyzed in the collected fluid. Since the inulin concentration in the perfusion fluid is known and inulin is not reabsorbed, it can be used for quality control (e.g. only collections that contain $100 \pm 5 \%$ of the expected amount of inulin are accepted) and to determine the "functional" perfusion rate. After finishing a first collection, the perfusion capillary can be withdrawn and a second perfusion system loaded with vehicle or an experimental substance inserted into the same whole, to repeat the measurements. This allows for paired comparisons, which minimizes the influence of variations in the perfused segment length. In general, the small oil block that is used for the first collection will be flushed downstream between collections.

Microperfusion has also been used to assess sodium reabsorption in the collecting duct. ${ }^{22} \mathrm{Na}$ is infused into the last surface loop of the distal tubule while urine is quantitatively collected and analyzed (3).

\section{Micropuncture analysis of tubuloglomerular feedback (TGF)}

The TGF describes a mechanism in which the tubular $\mathrm{NaCl}$ load is sensed at the end of the thick ascending limb by specialized tubular cells, the macula densa. These cells generate a signal to affect primarily afferent arteriolar tone, such that an inverse relationship is established between this tubular $\mathrm{NaCl}$ load and SNGFR of the same nephron (47;60). In doing so, the TGF helps to stabilize the $\mathrm{NaCl}$ load to further distal segments and contributes to autoregulation of renal perfusion and GFR. In the following, different approaches that have been used to study aspects of TGF by micropuncture are briefly outlined. For more details see $(62 ; 71)$.

Since the TGF mechanism is a single nephron event, studying TGF requires the use of techniques with single nephron resolution. One must produce a predictable change in $\mathrm{NaCl}$ concentration at the macula densa, and measure the glomerular response, i.e. the change in SNGFR. Alternative indices to SNGFR include measurement of $\mathrm{P}_{\mathrm{GC}}$ or $\mathrm{P}_{\mathrm{SF}}$ (however, differences in the symmetry around the operating point have to be considered (55)).

Simultaneously, orthograde microperfusion of the loop of Henle is performed at various flow rates downstream from an obstructing wax block to alter the electrolyte concentration and thus the luminal TGF signal at the macula densa. To minimize the influence from transport in the loop of Henle, TGF can also be assessed by retrograde perfusion from the early distal tubule (see Figure 6A). This approach has also been used to indicate that luminal $\mathrm{K}^{+}$is part of the physiological TGF signal (67). Because natural tubular flow is interrupted in this approach, this is called an open-loop approach.

A way to assess the ambient SNGFR-restraining influence of the macula densa is to determine the difference between SNGFR measured from distal tubular collections, i.e., under conditions of normal flow passing the macula densa, and SNGFR measured from proximal tubular collections, i.e., with interrupted flow to the macula densa and thus minimized TGF signal. This approach showed that the ambient SNGFR-restraining influence of the macula densa is missing in mice that lack the adenosine $\mathrm{A}_{1}$ receptor (70).

The physiological role of TGF is determined by its behaviour at the natural operating point where changes in SNGFR to a given alteration in the macula densa signal are greatest. Insights on the behaviour of TGF at the operating point are provided by closed-loop perturbation analysis: in a simple approach, the effectiveness of the TGF system is assessed by measuring early distal $\mathrm{Na}^{+}$delivery and SNGFR with or without adding small amounts of ATF to the late 
proximal tubule under free-flow conditions. Adding ATF to late proximal tubular fluid will increase the $\mathrm{NaCl}$ concentration at the macula densa; this will activate TGF and lower SNGFR thereby stabilizing distal $\mathrm{NaCl}$ delivery. Application of this approach showed that the ability to stabilize distal $\mathrm{Na}^{+}$and fluid delivery is impaired in mice lacking the adenosine $\mathrm{A}_{1}$ receptor (70). Alternatively, late proximal tubular flow rate is perturbed in free-flowing nephrons by adding or subtracting small amounts of fluid to the late proximal tubule, while the response in tubular flow rate just upstream from the perturbation is simultaneously measured by a noninvasive optical method (26). Using this elegant approach, the homeostatic efficiency of the TGF system to stabilize late proximal tubular flow rate against positive and negative perturbations is determined. This approach also provides information on the efficiency of the system to stabilize SNGFR or $\mathrm{P}_{\mathrm{GC}}$. Application of the approach in the rat revealed that TGF efficiency at the natural operating point is attenuated in diabetes mellitus (64). This could contribute to the development of diabetic glomerular sclerosis by exposing the glomerular mesangium to greater fluctuations in $\mathrm{P}_{\mathrm{GC}}$ and thus greater physical stress. This last method has not been applied in the mouse due to the relatively low ambient flow rates.

Finally, the TGF can be used as a tool to manipulate SNGFR in order to discriminate "primary" changes in proximal reabsorption from changes due to glomerulotubular balance (GTB). GTB refers to the load-dependent reabsorption in a nephron segment. To test for primary effects on tubular reabsorption, i.e. effects not explained by GTB, one must control for differences in load delivered to the tubule by glomerular filtration. To accomplish this, TGF can be used as a tool for manipulating SNGFR so that net proximal reabsorption could be determined as a function of SNGFR in each nephron. This approach has been used to show i) that there is a primary increase in proximal reabsorption in diabetes mellitus independent of glomerular hyperfiltration (57) and ii) that high salt intake does not lessen proximal tubular reabsorption or the influence of angiotensin II; high salt lowers angiotensin II in plasma and whole kidney, but increases the concentration in proximal tubular fluid. These unexpected observations indicate that the role of proximal tubular angiotensin II in salt-repletion is to stabilize nephron function rather than contribute to salt homeostasis (58).

\section{Perspectives}

Many basic aspects of kidney physiology and pathophysiology are still poorly understood. Whereas we have some ideas about the physical determinants of glomerular filtration under physiological conditions, still very little is known about the molecular determinants or in disease states. Determining glomerular hemodynamics in gene-targeted mice or pathophysiological models is challenging but potentially rewarding. Many questions remain with regard to renal transport pathways, their regulation, and their quantitative contribution under physiological conditions and in disease states. For example, we assume based on pharmacological studies and limited immunohistochemical evidence that it is the $\mathrm{Na}^{+}$-glucose cotransporters SGLT2 and SGLT1 that are critical for the near quantitative glucose uptake across the apical membrane of the earlier and later aspects of the proximal tubule, respectively. Micropuncture studies along the proximal tubule in gene knockout mice could provide direct evidence in this regard. Moreover, micropuncture in wild-type and gene knockout mice may help to quantitate functional changes of these transporters under pathophysiological conditions like diabetes. These $\mathrm{Na}^{+}$-glucose transporters are electrogenic and induce compensatory $\mathrm{K}^{+}$ fluxes out of the cells but, as mentioned above, we have not identified the molecular nature of these $\mathrm{K}^{+}$pathways in the early proximal tubule where most glucose is reabsorbed. Performing in vivo micropuncture on gene-knockout mice for candidate genes could provide answers. Similar approaches can be applied to assess the functional relevance of candidate genes for the regulation of transport processes like kinases or phosphatases. An important advantage of micropuncture is that the kidney is no longer a black box but that we can gain relevant qualitative and quantitative information on transport processes along the intact nephron. For 
example, downstream segments may compensate for a defect in the proximal tubule and total renal reabsorption and excretion are normal; the micropuncture approach, however, may still demonstrate the proximal defect and provide relevant quantitative insights.

We know little about the tubular fluid as a medium that helps to communicate between nephron segments and that coordinates transport functions along the nephron. Examples include the luminal angiotensin II system or the highly dynamic ATP-ADP-AMP/cAMP-adenosine system (63). Micropuncture studies to measure and manipulate endogenous luminal factors in the intact tubules provide an important opportunity to better understand their physiological and pathophysiological relevance.

Another important domain of renal micropuncture includes the TGF system. We still know relatively little about the importance of the TGF system for body homeostasis. For example, what is its quantitative role in short-term and long-term adaptation of salt homeostasis and blood pressure regulation? Does TGF resetting serve to increase early distal tubular salt delivery thereby facilitating salt excretion? What are the molecular determinants of TGF resetting? Interesting gene-targeted mouse models for that purpose are now available (e.g., for adenosine $A_{1}$ receptor or nitric oxide synthase 1).

Application of micropuncture techniques in the intact kidney will remain a gold standard to answer questions related to renal physiology and pathophysiology. The use of gene-targeted mouse models and the combination with studies in isolated segments and studies on the cellular and molecular level promises a powerful but challenging approach. The identification of functionally relevant questions requires an integrative understanding of renal function and the outlined approach requires a strengthening of collaborative efforts between experts of these methods. Potentially helpful developments also include the combination of micropuncture with new imaging techniques such as multiphoton microscopy, which along with the development of new fluorescent probes and innovative computer software may allow new insights on intracellular parameters in vivo and in real time mode (for review see $(2 ; 49)$ ).

\section{Acknowledgments}

The author was supported by the Deutsche Forschungsgemeinschaft, the Department of Veterans Affairs, the American Heart Association (0655232Y), and the National Institutes of Health (DK56248, DK28602, GM66232, DK070667, DK079784).

\section{Reference List}

1. Andreucci VE, Herrera-Acosta J, Rector FC Jr, Seldin DW. Measurement of single-nephron glomerular filtration rate by micropuncture: analysis of error. Am J Physiol 1971;221:1551-1559. [PubMed: 5124300]

2. Ashworth SL, Sandoval RM, Tanner GA, Molitoris BA. Two-photon microscopy: visualization of kidney dynamics. Kidney Int 2007;72:416-421. [PubMed: 17538570]

3. Bailey MA, Unwin RJ, Shirley DG. In vivo inhibition of renal 11 beta-hydroxysteroid dehydrogenase in the rat stimulates collecting duct sodium reabsorption. Clin Sci (Lond) 2001;101:195-198. [PubMed: 11473496]

4. Blantz RC. Effect of mannitol on glomerular ultrafiltration in the hydropenic rat. J Clin Invest 1974;54:1135-1143. [PubMed: 4418509]

5. Blantz, RC.; Tucker, BJ. Measurements of glomerular dynamics. In: Martinez-Maldonado, editor. Methods in pharmacology. Plenum Publishing Corporation; 1978. p. 141-163.

6. Braam B, Mitchell KD, Fox J, Navar LG. Proximal tubular secretion of angiotensin II in rats. Am J Physiol 1993;264:F891-F898. [PubMed: 8388654] 
7. Brenner BM, Falchuk KH, Keimowitz RI, Berliner RW. The relationship between peritubular capillary protein concentration and fluid reabsorption by the renal proximal tubule. J Clin Invest 1969;48:15191531. [PubMed: 5796362]

8. Brenner BM, Troy JL, Daugharty TM. The dynamics of glomerular ultrafiltration in the rat. J Clin Invest 1971;50:1776-1780. [PubMed: 5097578]

9. Colindres RE, Kramp RA, Allison ME, Gottschalk CW. Hydrodynamic alterations during distal tubular fluid collections in the rat kidney. Am J Physiol 1977;232:F497-F506. [PubMed: 879284]

10. Cortell S. Silicone rubber for renal tubular injection. J Appl Physiol 1969;26:158-159. [PubMed: 5762870]

11. Davidman M, Lalone RC, Alexander EA, Levinsky NG. Some micropuncture techniques in the rat. Am J Physiol 1971;221:1110-1114. [PubMed: 5111251]

12. Deen WM, Robertson CR, Brenner BM. A model of glomerular ultrafiltration in the rat. Am J Physiol 1972;223:1178-1183. [PubMed: 4654350]

13. Deen WM, Troy JL, Robertson CR, Brenner BM. Dynamics of glomerular ultrafiltration in the rat. IV. Determination of the ultrafiltration coefficient. J Clin Invest 1973;52:1500-1508. [PubMed: 4703234]

14. Falchuk KH, Berliner RW. Hydrostatic pressures in peritubular capillaries and tubules in the rat kidney. Am J Physiol 1971;220:1422-1426. [PubMed: 5574660]

15. Faria NJ, Dobbie H, Slater JM, Shirley DG, Stocking CJ, Unwin RJ. Simultaneous determination of anions in nanoliter volumes. Kidney Int 2005;67:357-363. [PubMed: 15610262]

16. Fromter E. The electrophysiological analysis of tubular transport. Kidney Int 1986;30:216-228. [PubMed: 3531676]

17. Fromter E, Gessner K. Free-flow potential profile along rat kidney proximal tubule. 1974. J Am Soc Nephrol 2001;12:2197-2206. [PubMed: 11562421]

18. Garcia NH, Plato CF, Garvin JL. Fluorescent determination of chloride in nanoliter samples. Kidney Int 1999;55:321-325. [PubMed: 9893143]

19. Garvin JL, Burg MB, Knepper MA. Ammonium replaces potassium in supporting sodium transport by the Na-K-ATPase of renal proximal straight tubules. Am J Physiol 1985;249:F785-F788. [PubMed: 2998206]

20. Giebisch G. Renal micropuncture techniques: A symposium. Yale J Biol Med 1972;45:456.

21. Good DW, Vurek GG. Picomole quantitation of ammonia by flow-through fluorometry. Anal Biochem 1983;130:199-202. [PubMed: 6869802]

22. Gottschalk, CW. A history of renal physiology to 1950. In: Seldin, DW.; Giebisch, G., editors. The Kidney Physiology and Pathophysiology. New York: Raven; 1992. p. 1-29.

23. Gottschalk, CW.; Lassiter, WE. Micropuncture methodology. In: Orloff, J.; Berliner, RW., editors. Handbook of Physiology Sect 8: Renal Physiology. Washington: American Physiological Society; 1973. p. 129-143.

24. Gottschalk CW, Mylle M. Micropuncture study of the mammalian urinary concentrating mechanism: evidence for the countercurrent hypothesis. Am J Physiol 1959;196:927-936. [PubMed: 13637248]

25. Hoenderop JG, van Leeuwen JP, van der Eerden BC, Kersten FF, van der Kemp AW, Merillat AM, Waarsing JH, Rossier BC, Vallon V, Hummler E, Bindels RJ. Renal Ca2+ wasting, hyperabsorption, and reduced bone thickness in mice lacking TRPV5. J Clin Invest 2003;112:1906-1914. [PubMed: 14679186]

26. Holstein-Rathlou NH. A closed-loop analysis of the tubuloglomerular feedback mechanism. Am J Physiol 1991;261:F880-F889. [PubMed: 1951720]

27. Huang DY, Osswald H, Vallon V. Intratubular application of sodium azide inhibits loop of Henle reabsorption and tubuloglomerular feedback response in anesthetized rats. Naunyn Schmiedebergs Arch Pharmacol 1998;358:367-373. [PubMed: 9774225]

28. Huang DY, Osswald H, Vallon V. Eukaliuric diuresis and natriuresis in response to the KATP channel blocker U37883A: micropuncture studies on the tubular site of action. Br J Pharmacol 1999;127:1811-1818. [PubMed: 10482911] 
29. Huang DY, Osswald H, Vallon V. Sodium reabsorption in thick ascending limb of Henle's loop: effect of potassium channel blockade in vivo. Br J Pharmacol 2000;130:1255-1262. [PubMed: 10903963]

30. Ichikawa I, Brenner BM. Local intrarenal vasoconstrictor-vasodilator interactions in mild partial ureteral obstruction. Am J Physiol 1979;236:F131-F140. [PubMed: 420294]

31. Jamison RL. Micropuncture study of superficial and juxtamedullary nephrons in the rat. Am J Physiol 1970;218:46-55. [PubMed: 5409892]

32. Kibble JD, Audsley N, Day JP, Green R. A new protocol for the measurement of picomole quantities of magnesium in rat renal tubular fluid. Exp Physiol 1998;83:11-22. [PubMed: 9483416]

33. Lameire NH, Lifschitz MD, Stein JH. Heterogeneity of nephron function. Annu Rev Physiol 1977;39:159-184. [PubMed: 322596]

34. Leyssac PP, Baumbach L. An oscillating intratubular pressure response to alterations in Henle loop flow in the rat kidney. Acta Physiol Scand 1983;117:415-419. [PubMed: 6880803]

35. Loffing J, Vallon V, Loffing-Cueni D, Aregger F, Richter K, Pietri L, Bloch-Faure M, Hoenderop JG, Shull GE, Meneton P, Kaissling B. Altered renal distal tubule structure and renal $\mathrm{Na}(+)$ and $\mathrm{Ca}$ (2+) handling in a mouse model for Gitelman's syndrome. J Am Soc Nephrol 2004;15:2276-2288. [PubMed: 15339977]

36. Lorenz JN. Considerations for the evaluation of renal function in genetically engineered mice. Curr Opin Nephrol Hypertens 2001;10:65-69. [PubMed: 11195054]

37. Lorenz JN, Gruenstein E. A simple, nonradioactive method for evaluating single-nephron filtration rate using FITC-inulin. Am J Physiol 1999;276:F172-F177. [PubMed: 9887093]

38. Ludwig, C. De viribus physicis secretionem urinae adjuvantibus. Thesis. Marburg: 1842.

39. Ludwig, CFW. Beitraege zur Lehre vom Mechanismus der Harnsekretion. Marburg: N.G Elwert; 1843.

40. Malnic G. Combined in vivo and in vitro approaches to analysis of renal tubule function. Exp Nephrol 1998;6:454-461. [PubMed: 9730662]

41. Malnic G, Vieira FL. The antimony microelectrode in kidney micropuncture. Yale J Biol Med 1972;45:356-367. [PubMed: 4638658]

42. Meneton P, Ichikawa I, Inagami T, Schnermann J. Renal physiology of the mouse. Am J Physiol Renal Physiol 2000;278:F339-F351. [PubMed: 10710537]

43. Nijenhuis T, Vallon V, van der Kemp AW, Loffing J, Hoenderop JG, Bindels RJ. Enhanced passive $\mathrm{Ca} 2+$ reabsorption and reduced $\mathrm{Mg} 2+$ channel abundance explains thiazide-induced hypocalciuria and hypomagnesemia. J Clin Invest 2005;115:1651-1658. [PubMed: 15902302]

44. Ramsay MA, Brown RHJ. Simplified apparatus and procedure for freezing point determinations upon small volumes of fluid. J Scient Instruments 1955;32:372.

45. Ramsey J, Brown R, Croghan P. Electrometric titration of chloride in small volume. J Exp Biol 1955;32:822-829.

46. Richards AN, Walker AM. Methods of collecting fluid from known regions of the renal tubules of Amphibia and of perfusing the lumen of a single tubule. Am J Physiol 1936;118:111-120.

47. Schnermann J, Wright FS, Davis JM, von Stackelberg W, Grill G. Regulation of superficial nephron filtration rate by tubulo-glomerular feedback. Pflugers Arch 1970;318:147-175. [PubMed: 5464606]

48. Shalmi M, Kibble JD, Day JP, Christensen P, Atherton JC. Improved analysis of picomole quantities of lithium, sodium, and potassium in biological fluids. Am J Physiol 1994;267:F695-F701. [PubMed: 7943365]

49. Sipos A, Toma I, Kang JJ, Rosivall L, Peti-Peterdi J. Advances in renal (patho)physiology using multiphoton microscopy. Kidney Int 2007;72:1188-1191. [PubMed: 17667980]

50. Star RA. Quantitation of total carbon dioxide in nanoliter samples by flow-through fluorometry. Am J Physiol 1990;258:F429-F432. [PubMed: 2106795]

51. Star RA, Burg MB, Knepper MA. Bicarbonate secretion and chloride absorption by rabbit cortical collecting ducts. Role of chloride/bicarbonate exchange. J Clin Invest 1985;76:1123-1130. [PubMed: 3930570]

52. Stocking CJ, Slater JM, Unwin R, Walter S, Folkerd E. An automated technique for the simultaneous determination of cations in nanoliter volumes. Kidney Int 1999;56:338-343. [PubMed: 10411711] 
53. Terada Y, Knepper MA. Continuous-flow quantitation of $\mathrm{Na}+$ and $\mathrm{K}+$ in nanoliter samples using chromogenic macrocyclic ionophores. Am J Physiol 1989;257:F893-F898. [PubMed: 2589487]

54. Thomson S, Bao D, Deng A, Vallon V. Adenosine formed by 5'-nucleotidase mediates tubuloglomerular feedback. J Clin Invest 2000;106:289-298. [PubMed: 10903345]

55. Thomson S, Vallon V, Blantz RC. Asymmetry of tubuloglomerular feedback effector mechanism with respect to ambient tubular flow. Am J Physiol 1996;271:F1123-F1130. [PubMed: 8997385]

56. Thomson, SC.; Blantz, RC. Biophysical basis of glomerular filtration. In: Alpern, RJ.; Hebert, SC., editors. Seldin and Giebisch's The Kidney. Academic Press; 2008. p. 565-587.

57. Thomson SC, Deng A, Bao D, Satriano J, Blantz RC, Vallon V. Ornithine decarboxylase, kidney size, and the tubular hypothesis of glomerular hyperfiltration in experimental diabetes. J Clin Invest 2001;107:217-224. [PubMed: 11160138]

58. Thomson SC, Deng A, Wead L, Richter K, Blantz RC, Vallon V. An unexpected role for angiotensin II in the link between dietary salt and proximal reabsorption. J Clin Invest 2006;116:1110-1116. [PubMed: 16557296]

59. Thomson SC, Tucker BJ, Gabbai F, Blantz RC. Functional effects on glomerular hemodynamics of short-term chronic cyclosporine in male rats. J Clin Invest 1989;83:960-969. [PubMed: 2921329]

60. Thurau K, Schnermann J. The Na concentration of the macula densa cells as a factor regulating glomerular filtration rate (micropuncture studies). 1965. J Am Soc Nephrol 1998;9:925-934. [PubMed: 9596093]

61. Vallon V. In vivo studies of the genetically modified mouse kidney. Nephron Physiol 2003;94:1-5.

62. Vallon V. Tubuloglomerular feedback in the kidney: insights from gene-targeted mice. Pflugers Arch 2003;445:470-476. [PubMed: 12548391]

63. Vallon V. P2 receptors in the regulation of renal transport mechanisms. Am J Physiol Renal Physiol 2008;294:F10-F27. [PubMed: 17977905]

64. Vallon V, Blantz RC, Thomson S. Homeostatic efficiency of tubuloglomerular feedback is reduced in established diabetes mellitus in rats. Am J Physiol 1995;269:F876-F883. [PubMed: 8594883]

65. Vallon V, Grahammer F, Richter K, Bleich M, Lang F, Barhanin J, Volk1 H, Warth R. Role of KCNE1dependent K+ fluxes in mouse proximal tubule. J Am Soc Nephrol 2001;12:2003-2011. [PubMed: 11562398]

66. Vallon V, Grahammer F, Volkl H, Sandu CD, Richter K, Rexhepaj R, Gerlach U, Rong Q, Pfeifer K, Lang F. KCNQ1-dependent transport in renal and gastrointestinal epithelia. Proc Natl Acad Sci U S A 2005;102:17864-17869. [PubMed: 16314573]

67. Vallon V, Osswald H, Blantz RC, Thomson S. Potential role of luminal potassium in tubuloglomerular feedback. J Am Soc Nephrol 1997;8:1831-1837. [PubMed: 9402084]

68. Vallon V, Richter K, Blantz RC, Thomson S, Osswald H. Glomerular hyperfiltration in experimental diabetes mellitus: potential role of tubular reabsorption. J Am Soc Nephrol 1999;10:2569-2576. [PubMed: 10589696]

69. Vallon V, Richter K, Heyne N, Osswald H. Effect of intratubular application of angiotensin 1-7 on nephron function. Kidney Blood Press Res 1997;20:233-239. [PubMed: 9398028]

70. Vallon V, Richter K, Huang DY, Rieg T, Schnermann J. Functional consequences at the singlenephron level of the lack of adenosine A1 receptors and tubuloglomerular feedback in mice. Pflugers Arch 2004;448:214-221. [PubMed: 14767772]

71. Vallon V, Schnermann J. Tubuloglomerular feedback. Methods Mol Med 2003;86:429-441. [PubMed: 12886786]

72. Vallon V, Schwark JR, Richter K, Hropot M. Role of $\mathrm{Na}(+) / \mathrm{H}(+)$ exchanger NHE3 in nephron function: micropuncture studies with S3226, an inhibitor of NHE3. Am J Physiol Renal Physiol 2000;278:F375-F379. [PubMed: 10710541]

73. Vallon V, Verkman AS, Schnermann J. Luminal hypotonicity in proximal tubules of aquaporin-1knockout mice. Am J Physiol Renal Physiol 2000;278:F1030-F1033. [PubMed: 10836992]

74. Vekaria RM, Unwin RJ, Shirley DG. Intraluminal ATP concentrations in rat renal tubules. J Am Soc Nephrol 2006;17:1841-1847. [PubMed: 16790512]

75. Vurek GG. Calcium measurement: picomole quantitation by continuous-flow colorimetry. Anal Biochem 1981;114:288-293. [PubMed: 7304918] 
76. Vurek GG. Flow-through nanocolorimeter for measurement of picomole amounts of magnesium and phosphate. Anal Lett 1981;14:261-269.

77. Vurek GG, Knepper MA. A colorimeter for measurement of picomole quantities of urea. Kidney Int 1982;21:656-658. [PubMed: 7098277]

78. Vurek GG, Warnock DG, Corsey R. Measurement of picomole amounts of carbon dioxide by calorimetry. Anal Chem 1975;47:765-767. [PubMed: 1137152]

79. Walker AM, Bott PA, Oliver J, MacDowel MC. The collection and analysis of fluid from single nephrons of the mammalian kidney. Am J Physiol 1941;134:580-595.

80. Walker AM, Hudson CL. The reabsorption of glucose from the renal tubule in Amphibia and the action of phlorhizin upon it. Am J Physiol 1936;118:130-143.

81. Walker AM, Oliver J. Methods for the collection of fluid from single glomeruli and tubules of the mammalian kidney. Am J Physiol 1941;134:562-579.

82. Wang T, Yang CL, Abbiati T, Schultheis PJ, Shull GE, Giebisch G, Aronson PS. Mechanism of proximal tubule bicarbonate absorption in NHE3 null mice. Am J Physiol 1999;277:F298-F302. [PubMed: 10444585]

83. Wearn JT, Richards AN. Observations on the composition of glomerular urine, with particular reference to the problem of reabsorption in the renal tubules. Am J Physiol 1924;71:209-227.

84. Windhager, EE. Micropuncture Techniques and Nephron Function. London: Butterworths; 1968.

85. Windhager, EE. Micropuncture and microperfusion. In: Gottschalk, CW.; Berliner, RW.; iebisch, GH., editors. Renal Physiology. People and Ideas. Bethesda: American Physiological Society; 1987. p. 101-129.

86. Wirz H. Der osmotische Druck des Blutes in der Nierenpapille. Helv Physiol Pharmacol Acta 1953;11:20-29. [PubMed: 13060867]

87. Wirz H. Der osmotische Druck in den corticalen Tubuli der Rattenniere. Helv Physiol Pharmacol Acta 1956;14:353-362. [PubMed: 13405356]

88. Wirz H, HARGITAY B, KUHN W. Lokalisation des Konzentrierungsprozesses in der Niere durch direkte Kryoskopie. Helv Physiol Pharmacol Acta 1951;9:196-207. [PubMed: 14849950]

89. Woda C, Mulroney SE, Halaihel N, Sun L, Wilson PV, Levi M, Haramati A. Renal tubular sites of increased phosphate transport and NaPi-2 expression in the juvenile rat. Am J Physiol Regul Integr Comp Physiol 2001;280:R1524-R1533. [PubMed: 11294778]

90. Wright FS, Giebisch G. Glomerular filtration in single nephrons. Kidney Int 1972;1:201-209. [PubMed: 4671212]

91. Zhelyaskov VR, Liu S, Broderick MP. Analysis of nanoliter samples of electrolytes using a flowthrough microfluorometer. Kidney Int 2000;57:1764-1769. [PubMed: 10760113] 

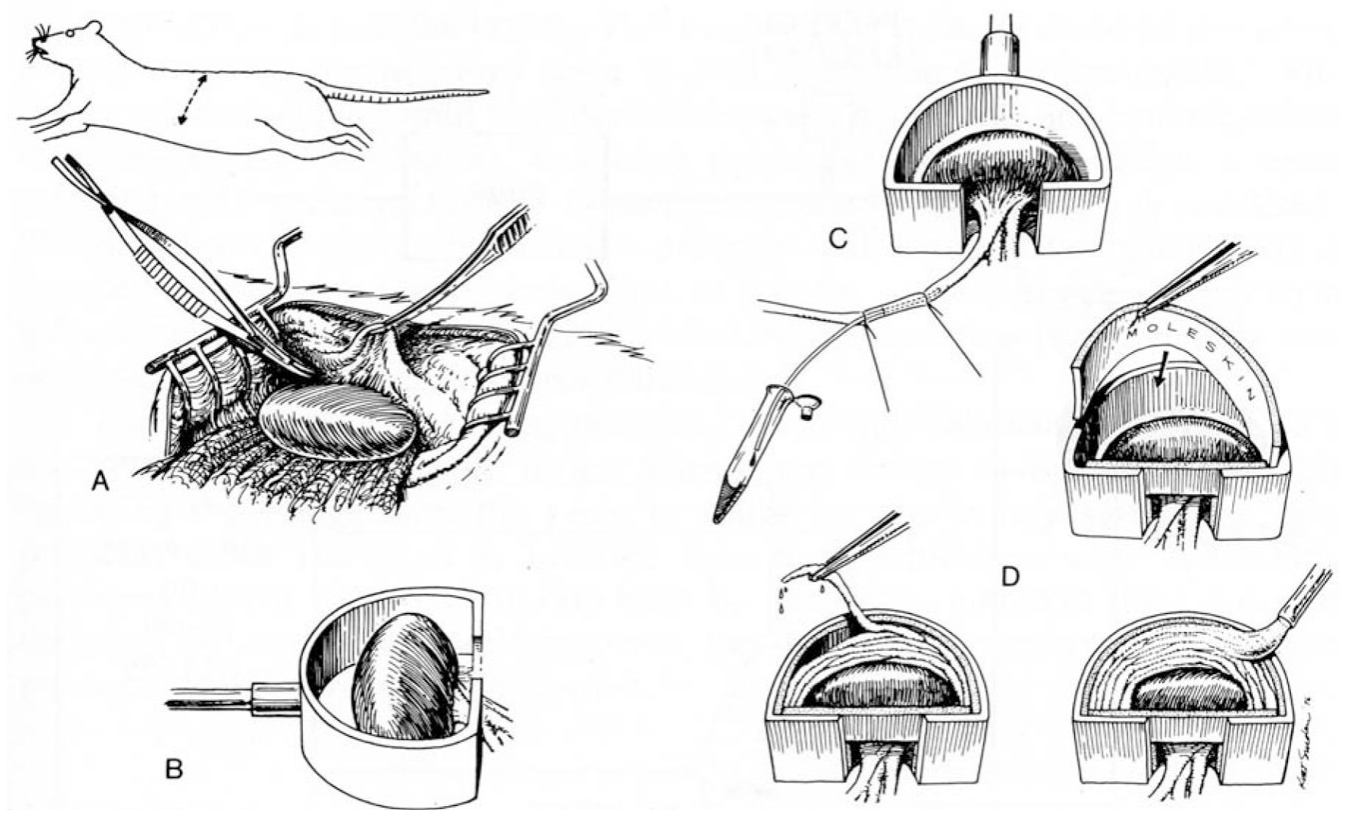

Figure 1. Preparation of the kidney for micropuncture experiments

(A) Following a flank incision, the perirenal fat and adrenal gland are carefully separated from the kidney. Without applying tension or torsion, the kidney is carefully overturned and placed in a Lucite cup such that the dorsal kidney surface faces up (B). In rats and mice, the kidney capsule should not be removed as it provides protection, and stabilizes inserted micropuncture pipettes. (C) In the rat, the ureter is catheterized for collection of urine; this is less useful in mice because of a tendency of catheters to obstruct. To immobilize the kidney, the Lucite cup is lined with moleskin (D) and cotton soaked in saline is carefully placed around the kidney. $2-3 \%$ agar is dripped onto the cotton to prevent leakage of the superfused mineral oil $\left(37^{\circ} \mathrm{C}\right)$ and establish an oil layer over the kidney surface of 1-2 mm (to keep the kidney surface warm and protected). Adapted from (5). 


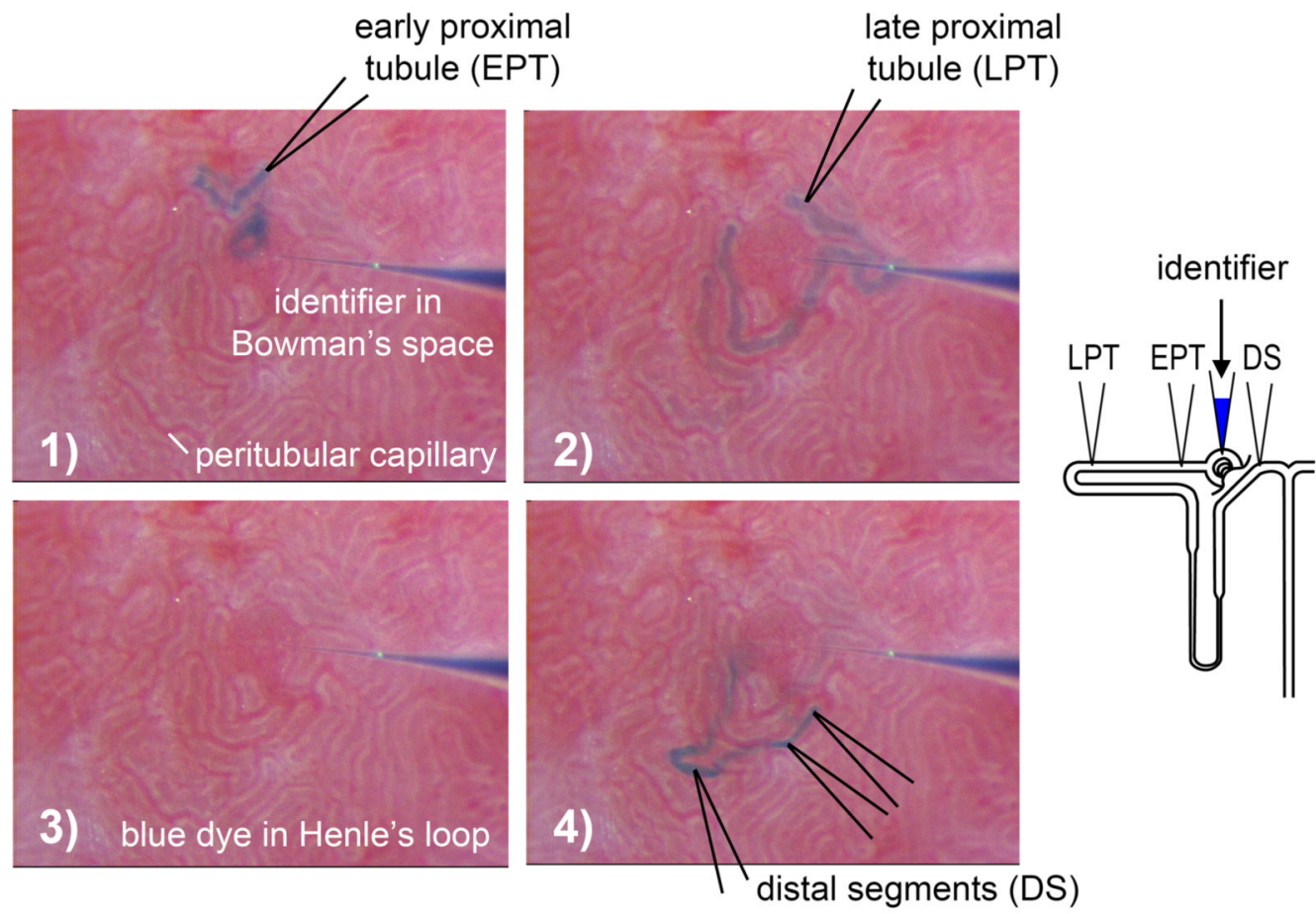

Figure 2. Identification of structures on the kidney surface accessible by micropuncture The nephron of a Munich-Wistar-Fromter rat is mapped by injecting small amounts of blue dye into Bowman's space and following it moving along the tubular system (1 to 4). 

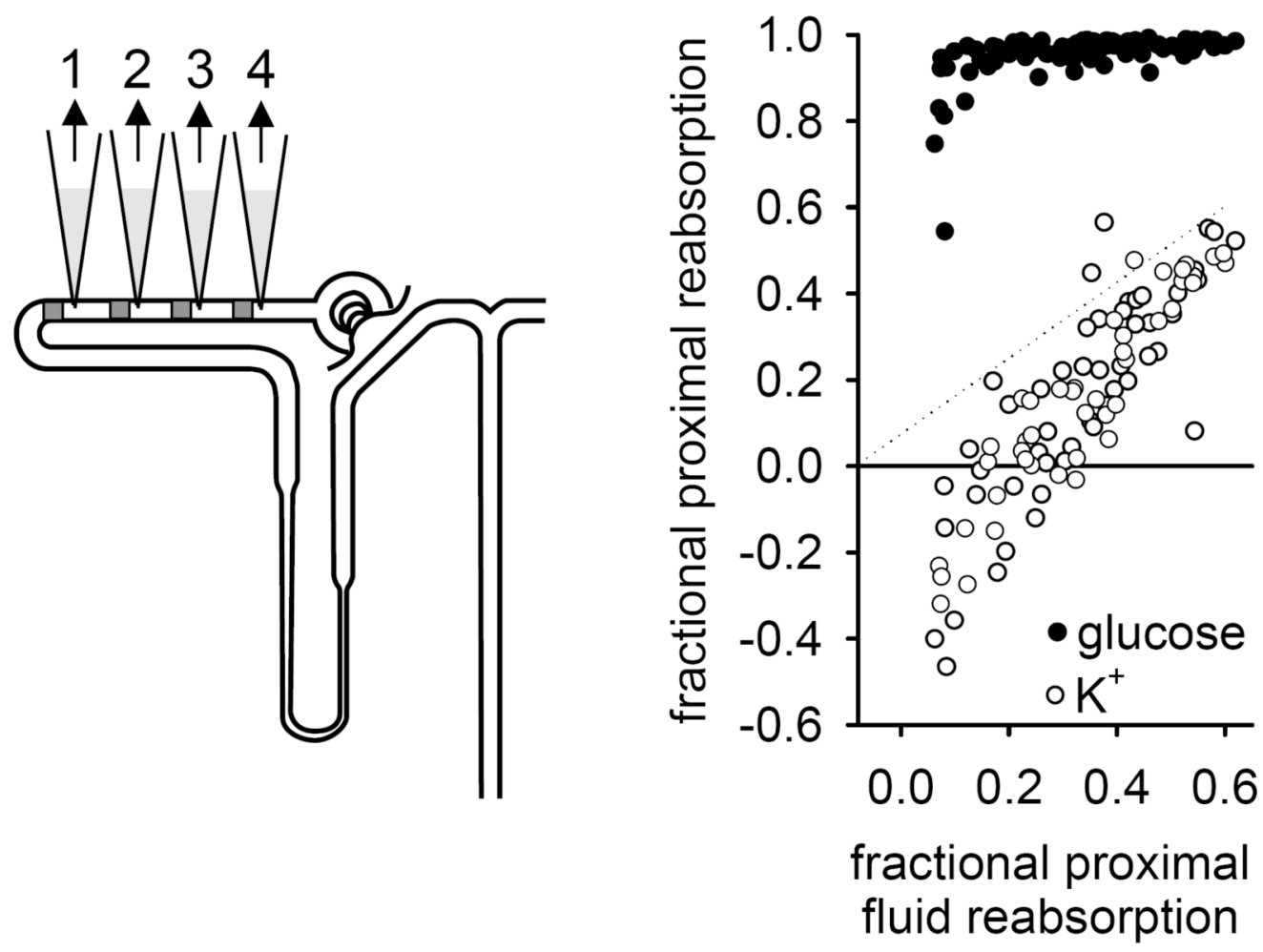

Figure 3. Reabsorption profiles of glucose and $\mathrm{K}^{+}$along the proximal tubule in mice using the fractional reabsorption of fluid as a reference for the puncturing sites

The fractional reabsorption of fluid, glucose and $\mathrm{K}^{+}$was determined in individual proximal collections. Glucose is rapidly and nearly quantitatively reabsorbed within the very early proximal tubule (low fractional reabsorption of fluid). In contrast, fractional reabsorption of $\mathrm{K}^{+}$is negative in the early proximal tubule indicating net $\mathrm{K}^{+}$fluxes into the lumen. Proximal tubular $\mathrm{K}^{+}$secretion serves to counteract the depolarizing effects of electrogenic $\mathrm{Na}^{+}$ reabsorption (e.g. $\mathrm{Na}^{+}$-glucose cotransport); the $\mathrm{K}^{+}$secretion is controlled by the regulatory $\beta$-subunit KCNE1, and mediated by an unknown $\mathrm{K}^{+}$channel in the early proximal tubule and by KCNQ1 in the late proximal tubule $(65 ; 66)$. Adapted from (66). 
A)

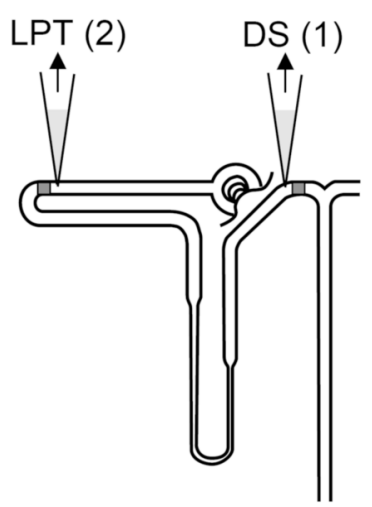

Urin (U)
B)
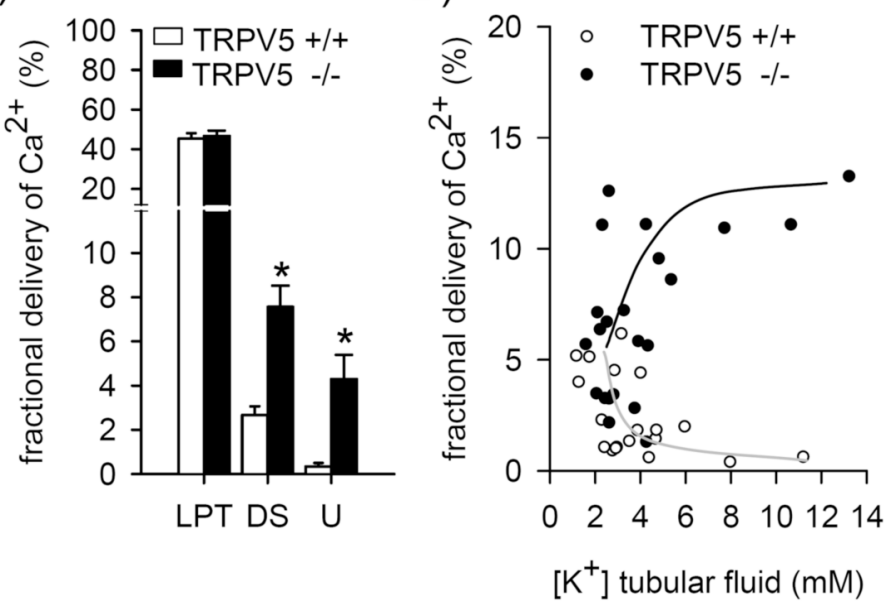

Figure 4. Reabsorption profiles of $\mathrm{Ca}^{2+}$ along the nephron and along the distal segments using luminal $\mathrm{K}^{+}$concentration as a reference for puncturing sites

A) $\mathrm{Ca}^{2+}$ reabsorption was unaffected in TRPV5 -/- mice up to the last surface loop of the proximal tubule (LPT); in contrast, mean $\mathrm{Ca}^{2+}$ delivery to puncturing sites within the distal segments (DS) accessible to micropuncture as well as urine (U) was significantly enhanced in TRPV5 -/- mice. * p<0.001 vs. TRPV5 +/+. B) The aim then was to try to directly assess $\mathrm{Ca}^{2+}$ reabsorption along the distal segments. Luminal $\mathrm{K}^{+}$concentration was used as a reference for the puncturing site with low and high concentrations indicating early and late aspects of the DS, respectively. Whereas the $\mathrm{Ca}^{2+}$ delivery profile indicated net reabsorption along the distal segments in TRPV5 +/+ mice, fractional $\mathrm{Ca}^{2+}$ delivery actually increased in TRPV5 -/mice, demonstrating a defect in $\mathrm{Ca}^{2+}$ reabsorption along the distal segments. Finally, comparing the fractional $\mathrm{Ca}^{2+}$ delivery in the late distal segment with the values in urine indicated significant compensation in the collecting duct of TRPV5 -/- (consistent with expression of TRPV6 in that segment). Adapted from (25). 

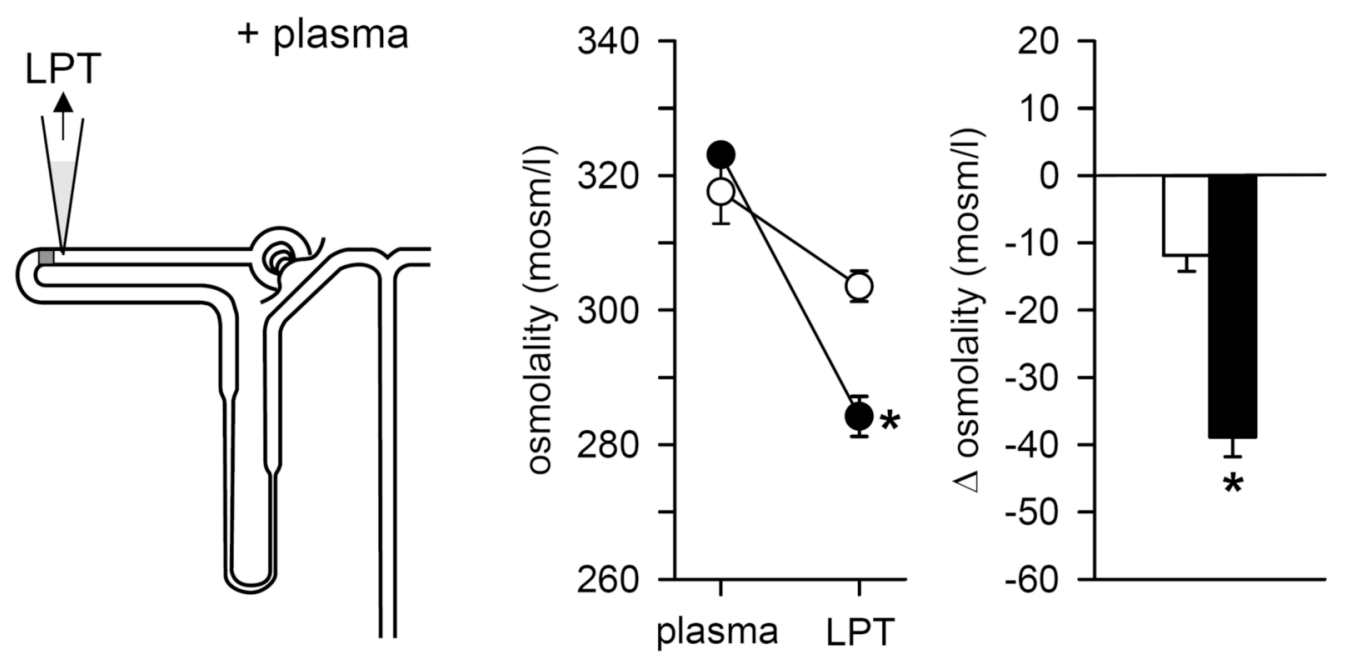

Figure 5. The transtubular osmotic gradient in late proximal tubular fluid ( $\Delta$ osmolality) $\Delta$ osmolality, i.e., the difference in osmolality between plasma and late proximal tubular fluid, is about $-12 \mathrm{mmHg}$ in AQP1 wild-type $(+/+)$ mice (i.e. a little more hypotonic in proximal tubular fluid) consistent with the principle that water follows the reabsorption of electrolytes. $\Delta$ osmolality of AQP1 knockout (-/-) mice was significantly increased to about $-40 \mathrm{mmHg}$. This demonstrates the functional importance of the water channel AQP1 for near-isosmolar reabsorption in the proximal tubule, and argues against a significant paracellular water reabsorption pathway and thus against a mechanism of solvent-drag in the proximal tubule. * $\mathrm{p}<0.001$ vs. AQP1 +/+. Adapted from (73). 

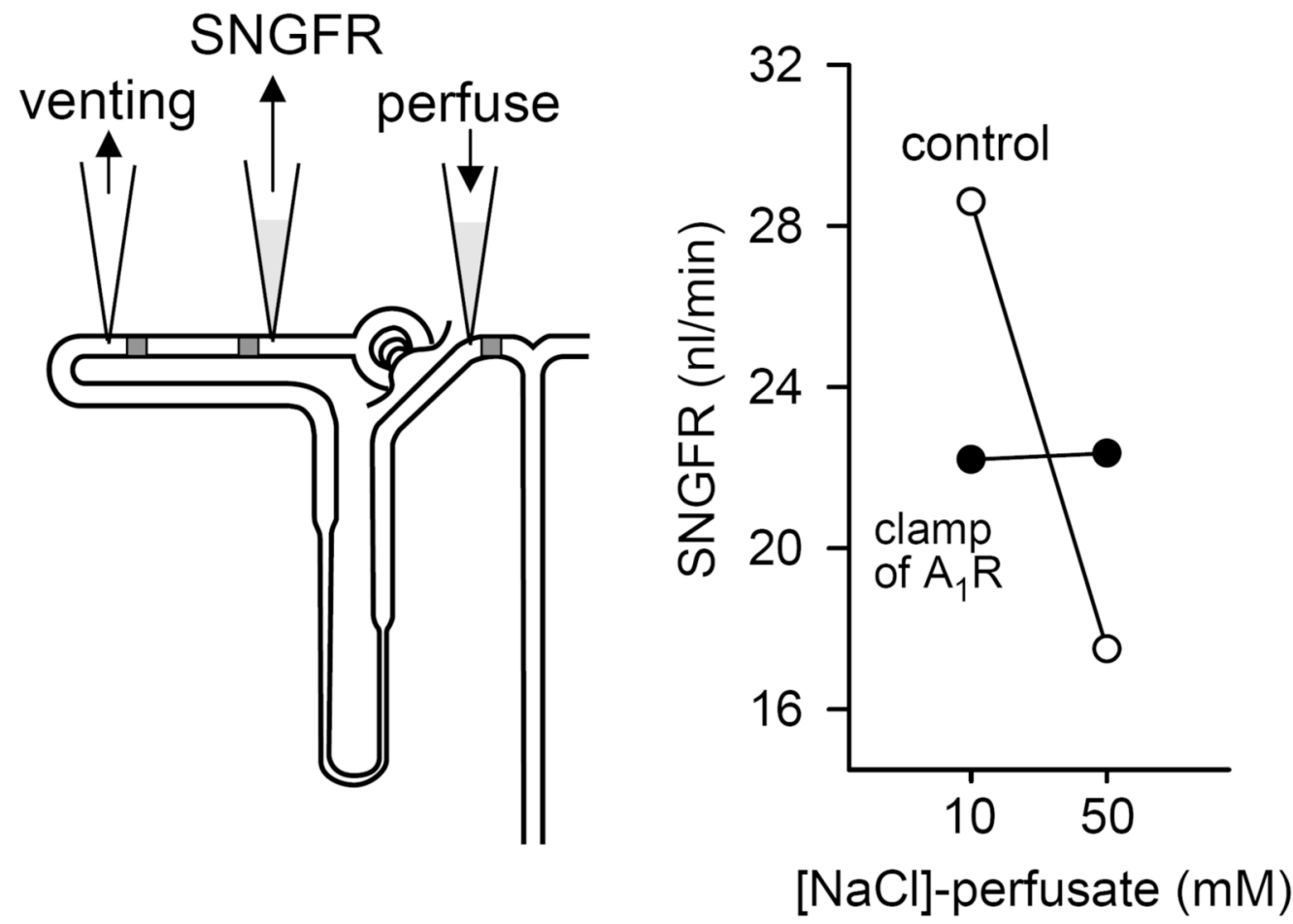

Figure 6. Tubuloglomerular feedback (TGF) assessed by retrograde perfusion of the macula densa The TGF response was assessed as the change in SNGFR (by paired proximal collections) during retrograde perfusion of the macula densa segment from the early distal tubule with artificial tubular perfusate containing either 10 or $50 \mathrm{mM} \mathrm{NaCl}$ to induce minimum and maximum stimulation of TGF. The fall in SNGFR observed in control experiments was completely absent when the local adenosine $A_{1}$ receptor $\left(A_{1} R\right)$ activation was "clamped" by pharmacological inhibition of adenosine generation and adding back constant amounts of an $\mathrm{A}_{1} \mathrm{R}$ agonist. These data indicate that local adenosine concentrations must fluctuate for normal TGF to occur, indicating that adenosine is a mediator of TGF. Adapted from (54). 
Table 1

Suggested composition of artificial tubular fluid (in $\mathrm{mM}$ )

\begin{tabular}{|l|c|c|c|}
\hline & early proximal & late proximal & distal \\
\hline $\mathrm{NaCl}$ & 113 & 130 & 45 \\
\hline $\mathrm{NaHCO}_{3}$ & 25 & 10 & 10 \\
\hline $\mathrm{KCl}$ & 4 & 4 & 3 \\
\hline $\mathrm{CaCl}_{2}$ & 2 & 2 & 1 \\
\hline $\mathrm{Na}_{2} \mathrm{HPO}_{4}$ & 1 & - & - \\
\hline $\mathrm{MgSO}_{4}$ & 1 & - & - \\
\hline glucose & 5 & - & - \\
\hline amino acid mix & 4 & & \\
\hline urea & 5 & 7.5 & 10 \\
\hline $\mathrm{pH}$ & 7.4 & 7.4 & 7.0 \\
\hline
\end{tabular}

FD\&C green No. 3 is added at $0.05 \%$ to stain the solution. 
Table 2

Suggested outer tip diameter of capillaries for different micropuncture applications in rats and mice.

\begin{tabular}{|l|c|c|}
\hline & rat & mouse \\
\hline tubule identifier & $1-2 \mu \mathrm{m}$ & $1 \mu \mathrm{m}$ \\
\hline micropressure system & $1-2 \mu \mathrm{m}$ & $1-2 \mu \mathrm{m}$ \\
\hline proximal fluid collection & $9-11 \mu \mathrm{m}$ & $7-9 \mu \mathrm{m}$ \\
\hline distal fluid collection & $7-9 \mu \mathrm{m}$ & $5-7 \mu \mathrm{m}$ \\
\hline peritubular blood collection & $13-16 \mu \mathrm{m}$ & $12-14 \mu \mathrm{m}$ \\
\hline perfusion "nanoliter pump" & $8-10 \mu \mathrm{m}$ & $7-9 \mu \mathrm{m}$ \\
\hline wax block & $12-14 \mu \mathrm{m}$ & $10-12 \mu \mathrm{m}$ \\
\hline
\end{tabular}




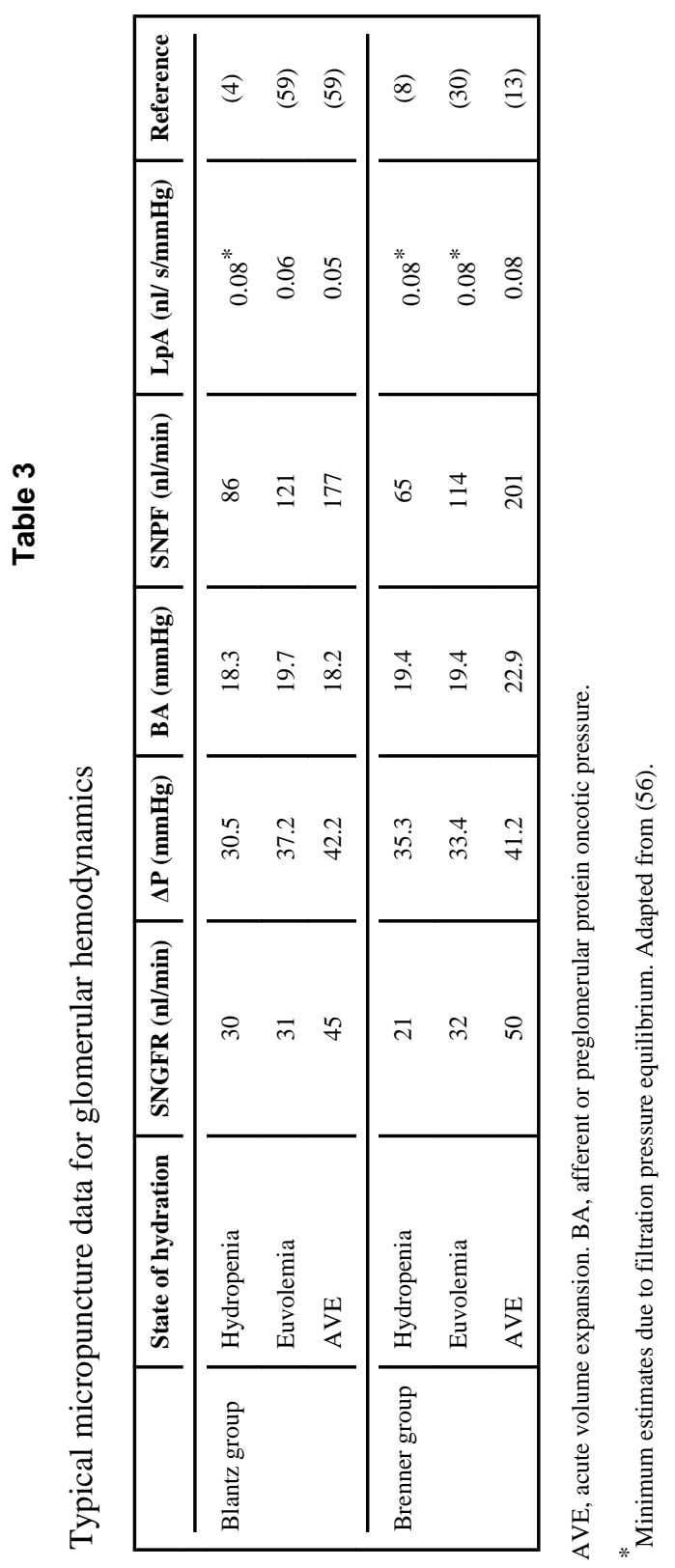

Pflugers Arch. Author manuscript; available in PMC 2010 October 14. 
Table 4

Direct analysis of substances in nanoliter samples of tubular fluid.

\begin{tabular}{|l|l|}
\hline Measured substance & Method \\
\hline $\mathrm{Na}^{+}$ & MFP (68); FTF (91); FTC (53); EAAS (48) \\
\hline $\mathrm{K}^{+}$ & MFP (68); FTC (53); EAAS (48) \\
\hline $\mathrm{Li}^{+}$ & EAAS (48) \\
\hline $\mathrm{Ca}^{2+}$ & FTC (75) or FTF (91) \\
\hline $\mathrm{Mg}^{2+}$ & FTC (76); EAAS (32) \\
\hline $\mathrm{NH}_{4}{ }^{+}$ & FTF (21) \\
\hline multiple cations $*$ & capillary zone electrophoresis (52) \\
\hline $\mathrm{Cl}^{-}$ & electrometric titration (45); FTC (51) or FTF (18;91) \\
\hline Bicarbonate & calorimetry (78;82) \\
\hline Phosphate & FTC (76;89) \\
\hline multiple anions $* *$ & capillary zone electrophoresis (15) \\
\hline CO & calorimetry (78); FTF (50); \\
\hline pH & antimony microelectrode (41) \\
\hline Osmolality & freezing point depression (44) \\
\hline Glucose & FTC (19); FTF (66) \\
\hline Urea & FTC (77) \\
\hline angiotensin II & radio-immuno assay (6;58) \\
\hline ATP & luciferin/luciferase enzyme reaction (74) \\
\hline
\end{tabular}

EAAS, electrothermal atomic absorption spectrophotometry; FTC, flow-through colorimetry; FTF, flow-through fluorometry; MFP, microflame photometer;

* $\mathrm{NH}_{4}, \mathrm{Na}, \mathrm{K}, \mathrm{Ca}, \mathrm{Li}, \mathrm{Mg}, \mathrm{Ba}$;

**

$\mathrm{Cl}^{-}$, nitrate, citrate, phosphate, bicarbonate, iothalamate. To the author's knowledge, instruments for MFP, FTC, FTF, and freezing point depression analysis in nanoliter volumes are currently not or no longer commercially available. 